\title{
MOTIVASI MEMBANGUN LEMBAGA PENDIDIKAN
}

Oleh : Azis

Mahasiswa Program Doktor Universitas Muhammadiyah Yogyakarta dan Dosen STAI

Masjid Syuhada Yogyakarta

\begin{abstract}
Improving the quality of educational institutions, good quality, efficiency, relevance or equalization should not start from the zero point (the system changes), because the educational process has been running for a long time and it has complex variables. Creative school always presents a variety of hallways for students to find a way out. Is the principal factors that influence the motivation that drives a person to meet the needs. At this point it becomes the driving force of motivation and behavioral determinants. While the components that must exist in educational institutions include a component of students, teachers, curriculum, facilities and managers. Keywords: motivation, creative, component.
\end{abstract}

\begin{abstract}
Abstrak
Peningkatan mutu lembaga pendidikan, baik mutu, efisiensi, relevansi atau pemerataan tidak harus dimulai dari titik nol (perubahan sistem), karena proses pendidikan sudah berjalan sejak lama dan memiliki variabel yang kompleks. Sekolah kreatif selalu menyuguhkan berbagai macam lorong untuk peserta didik agar menemukan jalan keluar. Faktor yang pokok adalah pengaruh motivasi yang menjadi pendorong seseorang untuk memenuhi kebutuhan. Pada titik ini motivasi menjadi daya penggerak dan penentu perilaku. Sedangkan komponen-komponen yang harus ada dalam lembaga pendidikan meliputi komponen siswa, guru, kurikulum, sarana prasarana dan pengelola.

Kata kunci : motivasi, kreatif, komponen
\end{abstract}

\section{A. Pendahuluan}

Lembaga pendidikan adalah badan atau instansi baik negeri maupun swasta yang melaksanakan kegiatan mendidik. Dengan kata lain badan atau instansi yang menyelenggarakan usaha pendidikan. Di Indonesia banyak lembaga pendidikan dengan tujuan, kurikulum dan lulusan yang berbeda-beda. ${ }^{1}$

Adanya lembaga-lembaga pendidikan dapat ditinjau dari segi penyelenggaraan, dalam Undang-undang RI tahun 1945 tentang pendidikan pada bab XIII pasal 31 disebutkan :

1. Tiap-tiap warga negara berhak mendapat pendidikan.

2. Pemerintah mengusahakan dan menyelenggarakan satu sistem pengajaran nasional yang diatur dengan undang-undang.

\footnotetext{
1 Suharsimi Arikunto dan Lia Yuliana, Manajemen Pendidikan, Yogyakarta : Aditia Media bekerjasama dengan FIP UNY, 2012, hlm. 15.
} 
Sesuai dengan undang-undang, kemungkinan untuk membantu pemerintah, adanya badan-badan atau yayasan swasta ikut menyelenggarakan pendidikan sepanjang tidak menyimpang dari ketentuan pemerintah. ${ }^{2}$

Dalam membangun lembaga pendidikan, biasanya diawali dengan merumuskan visi dan misi yang menunjukkan keunggulan lembaga tersebut. Visi lembaga harus berorientasi ke masa depan dan dikembangkan bersama warga sekolah, serta didukung berbagai input yang meliputi peserta didik, tenaga pendidik, kurikulum, sumber daya, kepemimpinan dan manajemen, sehingga lembaga pendidikan tersebut dinamakan lembaga yang sehat. Di samping merumuskan visi, juga harus merumuskan misi dan tujuan lembaga kemudian di-follow-up dengan tindakn nyata oleh komponen lembaga pendidikan secara efektif dan efisien. Hal tersebut merupakan salah satu manajemen strategi mutu, bahwa lembaga pendidikan harus menyampaikan visi, misi, nilai-nilai dan tujuan yang jelas, seperti yang diharapkan dan memperjelas arah mana yang akan dituju. ${ }^{3}$

Langkah selanjutnya, berangkat dari visi, misi dan tujuan peningkatan mutu tersebut, sekolah bersama-sama dengan masyarakatnya merencanakan dan menyusun program, yang sesuai dengan kebijakan nasional dan kunci pokok strategi tahun ini dan tahun mendatang. ${ }^{4}$

Dalam perspektif developmentalisme, lembaga pendidikan menjadi satu poros utama dalam melahirkan SDM yang berkualitas. Maka ada tiga hal yang menyebabkan pendidikan menjadi penting dalam mengembangkan SDM, Pertama, kemampuan untuk menghadapi perubahan nilai dan pluralitas. Kedua, kemampuan untuk memilih dengan baik, terutama dalam situasi transisi dan ketika diperhadapkan pada beberapa alternatif pilihan. Ketiga, kemampuan beadaptasi dengan cepat. ${ }^{5}$

Masalah pendidikan adalah masalah yang tidak pernah tuntas, karena menyangkut persoalan manusia dalam rangka memberi makna dan arah normal kepada

${ }^{2}$ Ibid., hlm. 16-17.

3 Edward Sallis, Total Quality Management in Education, Alih bahasa Ahmad Ali Riyadi Manajemen Mutu Pendidikan, , Yogyakarta : IRCiSoD, 2012, hlm. 215.

4 Suharyanta, Administrasi Pendidikan Islam : Telaah Musyawarah dan Prodesionalisme Discussion Principle of Profesional in Islam, Yogyakarta : Idea Press, 2012, hlm. 43.

${ }^{5}$ Muh. Djunaidi, Psikologi Transformatif dalam Pembangunan Pendidikan Nasional, diterbitkan dalam Jurnal Mukaddimah Vo. XVII, No. 30 Januari-Juni 2011, Yogyakarta : Kopertais III, 2011, hlm. 45.. 
eksistensi fitrinya. ${ }^{6}$ Hampir tidak ada satu negara pun dewasa ini di mana pendidikan tidak merupakan topik utama yang diperdebatkan. ${ }^{7}$ Karena tujuan pendidikan sesuai dalam Undang-undang No. 20 Tahun 2013 tentang Pendidikan Nasional menyatakan bahwa pendidikan adalah usaha sadar dan terencana untuk mewujudkan suasana belajar dan proses pembelajaran, agar peserta didik secara aktif mengembangkan potensi dirinya, untuk memiliki spiritual keagamaan, pengendalian diri, kepribadian, kecerdasan, akhak mulia serta ketrampilan yang diperlukan dirinya, masyarakat, bangsa dan negara.

Seluruh perbuatan manusia pasti dilandasi motivasi. Motivasi terkadang bersumber dari kebutuhan manusia terhadap sesuatu hal. Seringkali motivasi menjadi tujuan yang mempesona. Motivasi sebagai penyemangat dan konsepsi menuntut adanya pemenuhan. ${ }^{8}$ Maka untuk itu perlu motivasi untuk menggairahkan para pelaku untuk membangun kembali sebuah lembaga pendidikan yang kreatif dan sehat serta menghasilkan SDM yang berkualitas secara rohani dan fisiknya. Hal di atas dikuatkan oleh pendapat John W. Santrock motivasi adalah proses yang memberi semangat, arah dan kegigihan perilaku, artinya perilaku yang termotivasi adalah perilaku yang penuh energi, terarah dan bertahan lama. ${ }^{9}$

Peningkatan mutu lembaga pendidikan, baik mutu, efisiensi, relevansi atau pemerataan tidak harus dimulai dari titik nol (perubahan sistem), karena proses pendidikan sudah berjalan sejak lama dan memiliki variabel yang kompleks. Oleh karena itu perbaikan dan perkembangan yang sering melibatkan perubahan, pada hakekatnya merupakan proses pembaruan yang berkesinambungan atau penyesuaian yang terjadi terus menerus. ${ }^{10}$

Pembaruan atau perubahan yang bertitik tolak dari kenyataan yang ada relatif murah dan tidak akan menimbulkan gejolak sosial, karena komponen-komponen yang mengalami perubahan secara logis dan jelas merupakan pertumbuhan atau

\footnotetext{
${ }^{6}$ Yunus Hasyim Syam, Mendidik Anak Ala Muhammad, Yogyakarta : Penerbit Skesta, 2005, hlm.x.

${ }^{7}$ Muis Sad Iman, Pendidikan Partisipatik, Yogyakarta : Safiria Insanita Press, 2004, hlm. 2.

${ }^{8}$ Azis Abdullah, Urgensi Motivasi Berdakwah, diterbitkan dalam Mukaddimah Jurnal Pemikiran Islam Vo. XVII No. 30, Januari-Juni, Yogyakarta Kopertais III DIY, 2011, hlm. 94.

${ }^{9}$ John W. Santrock, Psikologi Pendidikan, diterjemah Tri Wobowo BS dari buku aslinya Educational Psychology, Jakarta : Prenadamedia, 2015, hlm.510.

${ }^{10}$ Yusuf Amir Faisal, Reorientasi Pendidikan Islam, Jakarta : Gema Insani Press, 1994. Hlm. 55.
} 
perkembangan dari yang sudah ada. Maka membangun kembali lembaga pendidikan merupakan kelanjutan dari sesuatu yang dimiliki sebelumnya. ${ }^{11}$

Berdasarkan pendahuluan di atas, maka dapat dirumuskan masalahnya yaitu bagaimana motivasi membangun lembaga pendidikan, bagaimana upaya membangun sekolah yang kreatif dan apa komponen-komponen yang mendukung lembaga pendidikan menjadi sehat?

\section{B. Pembahasan}

1. Motivasi Membangun

Secara psikologis ada persoalan yang harus dipecahkan dan mempersoalkan tentang sebab dan mengapa sebuah perilaku itu dilakukan. Dalam kajian psikologi, sesuatu dibalik perilaku manusia adalah faktor motivasi ${ }^{12}$

Setiap perbuatan yang dilakukan manusia baik yang rasional atau naluri, pada dasarnya merupakan wujud untuk menjaga keseimbangan hidup. Motivasi menjadi pendorong seseorang untuk memenuhi kebutuhan. Pada titik ini motivasi menjadi daya penggerak dan penentu perilaku. Dan juga sebagai suatu kontruk teoritis mengenai terjadinya perilaku yang meliputi pengaturan, pengarahan dan tujuan dari perilaku. ${ }^{13}$

Pendapat Gauzali yang dikutip oleh Ananto Pramandhika, mengelompokkan faktor-faktor motivasi menjadi dua kelompok, yaitu faktor eksternal (karakteristik oragnisasi) dan faktor internal (karakteristik pribadi). Faktor eksternal berupa lingkungan yang menyenangkan, tingkat kompensasi, supervisi yang baik, penghargaan, status dan tanggungjawab. Sedang faktor internal berupa kematangan pribadi, tingkat pendidikan, keinginan dan harapan pribadi dan lain-lain. ${ }^{14}$ Faktor-faktor tersebut sangat mendorong seseorang selalu berusaha membangun kembali lembaga pendidikan yang baik dan kreatif, untuk masa sekarang dan yang akan datang.

\footnotetext{
${ }^{11}$ Ibid.,

${ }^{12}$ Abdul Rahman Shaleh, Psikologi : Suatu Pengantar dalam Perspektif Islam, Jakarta : Kencana Prenada Media Group, 2009, hlm. 177-178.

${ }^{13}$ Ibid., hlm. 179, 182-183.

14 Ananto Pramandhika, Morivasi Kerja dalam Islam, diterbitkan di Jurnal UNDIP dan dipublikasi8kan melalui Internet dengan format PDF. hlm. 3.
} 
Lebih lanjut Azis Abdullah menegaskan bahwa motivasi adalah penyebab psikologis yang merupakan sumber dan tujuan dari tindakan dan perbuatan manusia. Penyebab ini bersifat kausal dan final, artinya manusia melakukan perbuatannya baik karena terdorong maupun karena tertarik. Sebagaian ilmuwan mengartikan bahwa motivasi sebagai pendorong artinya sebagai komplikasi dari motivasi dalam benak manusia dan tujuan yang akan dicapai. ${ }^{15}$ Sedang Robert E. Slavin mengartikan motivasi merupakan proses internal yang mengaktifkan, menuntut dan mempertahankan perilaku dari waktu ke waktu. ${ }^{16}$ Oleh karena itu manusia selalu aktif dalam proses membangun sebuah lembaga pendidikan.

Pendapat John yang dikutip oleh Ananto Pramandhika, menegaskan bahwa motivasi untuk bekerja dalam bidang perilaku keorganisasian (organizational Behavior), menerangkan kekuatan-kekuatan yang terdapat pada diri individu yang menjadi penyebab timbulnya tingkat, arah dan persistensi upaya yang dilaksanakan dalam bekerja. Oleh karena itu motivasi akan bersinggungan dengan faktor-faktor yang mempengaruhi motivasi seseorang. ${ }^{17}$ Sedangkan George R. Terry mendefinisikan motivasi adalah keinginan yang terdapat pada seseorang individu yang merangsang untuk melakukan tindakan. Dan yang merangsang motivasi untuk bertindak, adalah sesuai dengan hasil-hasil penelitian bahwa faktor-faktor yang mempengauhi motivasi pertama, kebutuhan-kebutuhan pribadi, kedua, tujuan-tujuan dan persepsi-persepsi orang atau kelompok yang bersangkutan dan ketiga yaitu cara dengan apa kebutuhan-kebutuhan dan tujuan-tujuan akan direalisasikan. ${ }^{18}$

2. Upaya Membangun Sekolah yang Kreatif

Sekolah yang diinginkan adalah sekolah yang mampu memberi jalan keluar dan dapat menyelesaikan konflik dengan lingkungan sekitar. Sekolah yang baik

${ }^{15}$ Azis Abdullah, Urgensi Motivasi Berdakwah, diterbitkan dalam Mukaddimah Jurnal Pemikiran Islam ........, hlm. 95.

${ }^{16}$ Robert Slavin, Educational Psychology : Theory anf Practice, Penerjemah Marianto Samosir, Psikologi Pendidikan : Teori dan Praktek, Jakarta : Indeks, 2011, hlm. 135.

17 Ananto Pramadhika, Motivasi Kerja Dalam Islam, diterbitkan di jurnal UNDIP dan dipublikasikan melalui internet dengan format pdf., hlm. 3.

${ }^{18}$ George R. Terry, Principle of Management, alih bahasa Winardi, Asas-asas Menejemen, Bandung : Alumni, 1986, hlm. 328. 
adalah yang dapat menyuguhkan metode kretaif untuk memancing daya kreativitas peserta didik. Oleh karena itu diperlukan mekanisme yang jelas. ${ }^{19}$

Mekanisme tidak hanya untuk pengelolaan proses pembelajaran, penentuan prosedur pengajaran, penetapan kurikulum, tapi juga rekrutmen pengajar dan bagaimana sekolah itu adaptable dengan lingkungan berada. Kendala utama penetapan mekanisme adalah sifat yang berpihak, sehingga harus diselesaikan adalah memilih dan memilah keberpihakan yang tepat dalam membangun lembaga pendidikan/sekolah. Oleh karena itu membangun sekolah/lembaga kreatif, maka patron keberpihakannya adalah humanisme. ${ }^{20}$

Sekolah/lembaga pendidikan yang kreatif tidak berpretensi untuk menyuguhkan pengetahuan "jadi" yang disakralkan peserta didik, dan tidak bersifat aksiomatik tapi mengedepankan elastisitasi. Sekolah kreatif selalu menyuguhkan berbagai macam lorong untuk peserta didik agar menemukan jalan keluar. Dalam sekolah kreatif. $1+1$ tidak selalu $=2$ (secara pasti), artinya angka 2 tidak mejadi satu-satunya alternatif jawaban bagi $1+1$. Misalkan 1 pisang +1 monyet maka jawaban tidak mutlak 2 , karena dua variabelnya berbeda, bisa jadi jawabannya 1 pisang dan 1 monyet atau 1 hewan 1 buah. $^{21}$

Sekolah kreatif mendorong sang pengajar untuk selalu aktif dan berusaha untuk mencari metodologi-metodologi yang tepat, pada akhirnya tidak hanya menciptakan anak-anak kreatif, tapi guru juga kreatif. Artinya dihadapan pendidikan guru tidak boleh merasa paling tahu atas satu problem yang ada. ${ }^{22}$ Sementara Abuddin Nata (235) mendefinisikan guru kreatif adalah guru yang memiliki kompetensi kepribadian yang baik, yang mendukung pelaksanaan tugas sebagai guru yang harus mengajar, membimbing, memberi teladan yang baik, mengembangkan bakat dan potensi dan bertanggung jawab atas tugasnya. ${ }^{23}$ Kompetensi keperibadian menjadi salah satu syarat bagi guru yang profesional. Di dalam Undang-undang Nomor 14 Tahun 2005 tentang guru dan dosen disebutkan,

${ }^{19}$ Muh. Djunaidi, Psikologi Transformatif dalam Pembangunan Pendidikan Nasional, ...... hlm. 50.

${ }^{20}$ Ibid., hlm. 50-51.

${ }^{21}$ Ibid., hlm. 51-52.

${ }^{22}$ Ibid., hlm. 52.

${ }^{23}$ Abuddin Nata, Kapita Selekta Pendidikan Islam, Isu-isu Kontemporer tentang Pendidikan Islam, Jakarta : PT. Raja Grafindo Persada, 2013, hlm. 235. 
seorang guru yang profesional harus memiliki empat kompetensi yang baik dan unggul, yaitu : pertama, kompetensi akademik, yaitu kemampuan menguasai bahan yang akan diajarkan secara mendalam dan mahir, selalu diperbaharui dan dikembangkan sesuai perkembangan ilmu pengetahuan. Kedua, kompetensi pedagogik yaitu kompetensi yang terkait dengan kemampuan guru dalam menguasai metode dan pendekatan menyampaikan materi secraa efektif dan efisien. Ketiga, kompetensi kepribadian yaitu berkaitan dengan kerpribadian dan karakter guru yang baik, sehingga memiliki daya dorong dan daya tarik bagi peserta didik. Keempat, yang berkaitan dengan kompetensi sosial, yakni kemampuan guru untuk membangun komunikasi dan interaksi yang sinergis dan harmonis dengan peserta didik, orang tua, stakeholder dan masyarakat.

Selain harus memiliki guru yang kreatif di atas, guru harus berkarakter. Maksud guru yang berkarakter adalah guru yang memiliki jati diri, sifat dan watak dasar serta chemistry yang unik dan jelas serta berbeda dengan orang lain, guru yang terbina potensi jasmani, rohani, intelektual, sosial dan berbagai kompetensi lain secara utuh. ${ }^{24}$

Untuk mewujudkan proses pembelajaran sekolah kreatif, perlu didukung komponen-komponen yang saling berinteraksi dan berinterelasi satu sam lain, komponen yang dimaksud meliputi tujuan, materi pelajaran, metode atau strategi pembelajaran, media dan evaluasi ${ }^{25}$

\section{Komponen Lembaga Pendidikan}

Secara umum bahwa dalam lembaga pendidikan selalu ada komponenkomponen yang penting dan menentukan keberhasilan lembaga tersebut, yaitu :

a. Komponen siswa, yaitu subyek belajar yang menurut jenis dan sifat lembaganya dapat disebut sebagai siswa, mahasiswa, peserta kursus.

b. Komponen guru, yaitu subyek yang memberikan pelajaran, yang dapat disebut guru, dosen, penyaji, penatar.

${ }^{24}$ Ibid., hlm. 237.

${ }^{25}$ Wina Sanjaya, Strategi Pembelajaran Berorientasi Standar Proses Pendidikan, Jakarta : Kencana Prenadamedia, 2014, hlm. 58. 
c. Komponen kurikulum, yaitu materi atau bahan pelajaran yang diajarkan, yang memberikan ciri pada lembaga pendidikan tersebut dan mencerminkan kualitas lulusannya.

d. Komponen sarana dan prasarana, yaitu komponen penunjang terlaksananya proses pengajaran.

e. Komponen pengelola, yaitu orang-orang yang mengurus penyelenggaraan lembaga pendidikan, menyangkut pengelolaan dalam memimpin, mengorganisasikan, mengarahkan, membina dan mengurus tata laksana lembaga. Termasuk dalam komponen pengelola adalah kepala sekolah, petugas bimbingan, pustakawan, staf tata usaha, bendaharawan, pensuruh, penjaga malam. ${ }^{26}$

Proses selanjutnya institusi-institusi pendidikan perlu menciptakan pendekatan yang logis dan inetgral dalam manajemen, karena akan meningkatkan komitmen pengelola. Motivasi, keahlian dan antusiasme dapat menjamin mutu, kemudian harus melibatkan banyak orang dalam suatu institusi. Setiap orang, manajer institusi, guru, maupun staf bertanggung jawab dalam peranannya menyampaikan layanan mutu. ${ }^{27}$

Dengan demikian misi reformasi pendidikan nasional dan SDM dapat dirumuskan sebagai berikut :

1. Pengelolaan pendidikan dan pengembangan SDM secara profesional.

2. Penyelenggaraan pendidikan dan pengembangan SDM melibatkan pemerintah, masyarakat dan individu-individu.

3. Pengembangan kurikulum pendidikan nasional mengakomodasikan unsur-unsur praktis dan teoritis sesuai kebutuhan.

4. Menjadikan tenaga kependidikan dan SDM (guru, pelatih, pengelola dan pimpinan) sebagai lambang dan contoh dari masyarakat yang beradab dan demokratis.

\footnotetext{
${ }^{26}$ Suharsimi Arikunto dan Lia Yuliana, Manajemen Pendidikan ........ hlm. 15-16.

${ }^{27}$ Edward Sallis, Total Quality Management in Education, Alih bahasa Ahmad Ali Riyadi Manajemen Mutu Pendidikan ....... hlm. 262.
} 
5. Mengupayakan tersedianya pembiayaan pendidikan yang wajar sehingga mencerminkan ada komitment pemerintah dalam lembaga pendidikan. ${ }^{28}$

Para praktisi pendidikan sepakat bahwa lembaga pendidikan bisa berjalan dibangun atas beberapa komponen dasar, seperti guru, murid, peserta didik,bangunan, fisik, media pembelajaran dan sebagainya. Komponen yang mendasar yaitu komponen manusia dan merupakan faktor yang paling menentukan. Unsur kedua yang juga dianggap penting yaitu murid atau peserta didik sebagai objek dan subyek pendidikan. Dalam proses pembelajaran guru dan murid memegang peranan penting, mempunyai potensi dan mengalami proses perkembangan. ${ }^{29}$

Menghadapi tuntutan perubahan akibat kompetisi global dan kemajuan teknologi, pemimpin lembaga harus mampu mengelola sumber daya manusia dengan fokus. Dengan demikian SDM dalam pendidikan merupakan faktor kunci untuk jalannya lembaga pendidikan kini dan akan datang. ${ }^{30}$

C. Kesimpulan

Berdasarkan pembahasan di atas, dapat disimpulkan bahwa secara psikologis dibalik kesuksesan seseorang dalam aktivitasnya termasuk membangun lembaga pendidikan adalah satu faktor yaitu motivasi, sebagai penggerak dan pendorong untuk mewujudkan dalam kenyataan, seperti halnya lembaga (sekolah) pendidikan. Sekolah/lembaga pendidikan yang kreatif adalah mencoba membangun satu konstruksi relasi guru dan siswa yang berbasis kesetaraan. Dan secara umum komponen-komponen yang harus ada dalam lembaga pendidikan meliputi komponen siswa, guru, kurikulum, sarana prasarana dan pengelola.

${ }^{28}$ A. Malik Fadjar dkk, Platform Reformasi Pendidikan dan Pengembangan Sumber Daya Manusia, Jakarta : Logos Wacana Ilmu, 2001, hlm. 42-44.

${ }^{29}$ Fuad Arif Noor, Manajemen Peserta Didik Raudhatul Athfal (RA), diterbitkan dijurnal Al-Manar STAIMS Vol. 4, No. 2 Desember 2015, hlm. 131. dan dipublikasikan secara on line di webb STAIMS Yogyakarta.

${ }^{30}$ Desy Aniqotsunainy, Penerapan Fungsi Perencanaan Sumber Daya Manusia dalam Pendidikan, diterbitkan dijurnal Al-Manar STAIMS Vol. 4, No. 2 Desember 2015, hlm. 68-69. dan dipublikasikan secara on line di webb STAIMS Yogyakarta. 


\section{DAFTAR PUSTAKA}

Abdul Rahman Shaleh, Psikologi : Suatu Pengantar Dalam Perspektif Islam, Jakarta : Kecana Prenada Media Group, 2009.

Abuddin Nata, Kapita Selekta Pendidikan Islam, Isu-isu Kontemporer tentang Pendidikan Islam, Jakarta : PT. Raja Grafindo Persada, 2013.

Ananto Pramadhika, Motivasi Kerja Dalam Islam, diterbitkan di Jurnal UNDIP dan dipubkikasikan melalui internet dengan format pdf.

Azis Abdullah, Urgensi Motivasi, diterbitkan dalam Mukaddimah Jurnal Pemikiran Islam Vol. XVII. No. 30 Januari-Juni, Yogyakarta : Kopertais III DIY, 2011

A Malik Fadjar dkk, Platform Reformasi Pendidikan dan Pengembangan Sumber Daya Manusia, Jakarta : Logos Wacana Ilmu, 2001.

Desy Aniqotsunainy, Manajemen Peserta Didik Radudhatul Athfal (RA), diterbitkan dijurnal Al-Manar STAIMS Vol. 4, No. 2 Desember 2015 dan dipublikasikan secara on line di webb. STAIMA Yogyakarta.

Edward Sallis, Total Quality Management in Education Manajemen Mutu Pendidikan, Alih bahasa Ahmad Ali Riyadi, Yogyakarta : IRCiSoD, 2012.

Fu'ad Arif Noor, Manajemen Peserta Didik Radudhatul Athfal (RA), diterbitkan dijurnal Al-Manar STAIMS Vol. 4, No. 2 Desember 2015 dan dipublikasikan secara on line di webb. STAIMA Yogyakarta

George R. Terry, Principles of Management, alih bahasa Winardi, Asas-asas Menejemen, Bandung : Alumni, 1986.

John W. Santrock, Psikologi Pendidikan, diterjemah Tri Wibowo BS dari buku aslinya Educational Psychology, Jakarta : Prenadamedia, 2015.

Muh. Djunaidi, Pendidikan Transformatif dalam Pembangunan Pendidikan Nasional, diterbitkan dalam Mukaddimah Jurnal Pemikiran Islam Vol. XVII, No. 30 JanuariJuni, Yogyakarta: Kopettais III DIY, 2011.

Muis Sad Iman, Pendidikan Partisipatik, Yogyakarta : Safiria Insania Press, 2004.

Robert Slavin, Educational Psychology : Theory and Practice, Penerjemah Marianto Samosir, Psikologi Pendidikan : Teori dan Praktek, Jakarta : Indeks, 2011. 
Suharyanta, Administrasi Pendidikan Islam : Telaah Musyawarah dan Profesionalisme) Discussion Principle of Profesional in Islam, Yogyakarta : Idea Press, 2012.

Suharsimi Arikunto dan Lia Yuliana, Manajemen Pendidikan, Yogyakarta : Adita Media bekerjasama dengan FIP UNY, 2012.

Yunus Hasyim Syam, Mendidik Anak Ala Muhammad, Yogyakarta : Penerbit Skesta, 2005.

Yusuf Amir Faisal, Reorientasi Pendidikan Islam, Jakarta : Gema Insani Press, 1995.

Wina Sanjaya, Strategi Pembelajaran Berorientasi Standar Proses Pendidikan, Jakarta : Kencana Prenadamedia Group, 2014. 